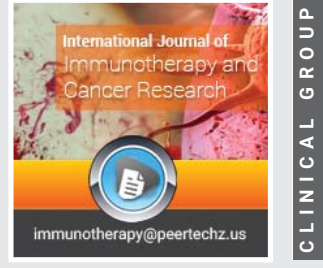

Case Report

\section{A case of denosumab-associated}

\section{hyperparathyroidism: A differential}

\section{diagnostic challenge}

\author{
Emin Taşkıran*, Sevnaz Şahin, Sumru Savaş, Zeliha Fulden \\ Saraç and Selahattin Fehmi Akçiçek
}

MD, Department of Geriatrics, Ege University Hospital, Bornova/Izmir, Turkey

\begin{abstract}
ISSN: $2455-8591$
Received: 27 September, 2021

Accepted: 07 October, 2021

Published: 08 October, 2021

*Corresponding authors: Emin Taşkıran, MD, Department of Geriatrics, Ege University Hospital, Bornova/ Izmir, Turkey, Tel: +905300670980;

E-mail: emintaskiran@yahoo.com

ORCID: https://orcid.org/0000-0002-4709-4222

Keywords: Osteoporosis; Denosumab; Hyperparathyroidism

Copyright: (C) 2021 Taşkıran E, et al. This is an open-access article distributed under the terms of the Creative Commons Attribution License, which permits unrestricted use, distribution, and reproduction in any medium, provided the original author and source are credited.
\end{abstract}

https://www.peertechzpublications.com

\section{Introduction}

Denosumab is a relatively new medicine that has become the second option in the treatment of biphosphonate-resistant or intolerant osteoporosis. Subcutaneous injection with 6-month intervals, approval of its usage in stage 3-4 CKD and not having gastrointestinal side effects are advantages of denosumab. However, it has some disadvantages like requiring monitoring serum levels of calcium and vitamin $\mathrm{D}$ before each injection.

\section{Case report}

An 85-year old female was referred with waist pain to the outpatient clinic of our department. She told that the pain started about 3 weeks ago while she was sitting in the chair. During the last 3 weeks, the pain existed and it was relieved with lying on the bed, aggravated with movement. She needed paracetamol 3 times a day and ibuprofen 2 times a day to alleviate the pain. She said that 2 weeks before the waist pain started, she had had the fourth denosumab injection. When we checked laboratory results history, we found normal serum calcium, phosphorus, and vitamin D levels $(8.8 \mathrm{mg} / \mathrm{dl}, 3.1 \mathrm{mg} /$ $\mathrm{dl}$, 32ng/l respectively) before denosumab injection. After the injection, she did not apply to the clinic. In her physical examination, she came to the examination room with a wheelchair. She had a sensitive point with pain on her lumbar vertebrae. Lower extremity movements were painful and muscle strength was reduced bilaterally. Vital signs and other systemic examinations were normal. On her laboratory tests serum Parathormone (PTH), calcium, phosphorus, vitamin D levels were $487 \mathrm{ng} / \mathrm{l}, 8.6 \mathrm{mg} / \mathrm{dl}, 0.6 \mathrm{mg} / \mathrm{dl}$, $30 \mathrm{ng} / \mathrm{mL}$ respectively. She did not have a chronic renal disease and another bone metabolism disease except for osteoporosis. Her X-ray revealed a height loss in L3 lumbar vertebrae. Spinal MR indicated that it was an acute fracture. However, we could not explain hyperparathyroidism in the absence of hypocalcemia and low vitamin D levels. Thus, we started to investigate primary hyperparathyroidism in the patient. Neck ultrasonography did not show any abnormal findings associated with parathyroid glands. Parathyroid scintigraphy resulted with normal activity in parathyroid glands. During her follow-up, the PTH level reduced with time. Spontaneous regression of PTH level led us to think of an association between denosumab injection and hyperparathyroidism. The challenging point for us was that the patient had normal serum calcium and vitamin $\mathrm{D}$ level with normal renal function.

\section{Discussion}

In the literature, Mazokopakis [1] first reported a similar case in 2018, a 62-year old woman with normal electrolytes and high PTH level after 3 months of denosumab injection. In a cohort of 60 patients with metastatic prostate cancer who received at least one dose of denosumab $(120 \mathrm{mg}), 42$ patients (70\%) developed hypocalcemia, seven (11.6\%) developed highgrade hypocalcemia, and nine $(15 \%)$ required hospitalization for intravenous calcium supplementation [2]. In our case, although the patient's baseline serum calcium, phosphorus and vitamin D levels were normal, the levels were close to the 
lowest threshold for all markers. Her risk for malnutrition was high and she was not eager to take oral nutritional supplements. Together with inadequate oral calcium and vitamin D intake, hypocalcemic effect of denosumab might have triggered exaggerated parathormone secretion. Previous literature suggests that hypocalcemic effects of denosumab starts after the injection, reaches the nadir level on $17^{\text {th }}$ day and resolves spontaneously on the $25^{\text {th }}$ day [3]. In this case, her serum calcium and vitamin D levels were normal before denosumab injection. Five weeks after the denosumab injection, on her presentation with osteoporotic vertebral fracture, laboratory tests revealed normal serum calcium and vitamin D levels again. Probably, bone fracture and transient hypocalcemic period which we could not detect during the 5- week period contributed together for hyperparathyroidism.

\section{Conclusion}

In conclusion, physicians should take into consideration that high PTH levels might be associated with denosumab therapy if the possibility of primary hyperparathyroidism is eliminated by neck ultrasonography and parathyroid gland scintigraphy. Close following-up the patient and replacing inadequate or near inadequate levels of serum calcium and vitamin $\mathrm{D}$ are key factors for preventing denosumab-

associated hyperparathyroidism. It should be kept in mind that PTH level may stay at high levels although serum calcium and vitamin D levels return to normal, especially when it exists together with acute bone fracture. Denosumab-associated hyperparathyroidism can spontaneously recover in 2 to 3 months if the patient takes adequate calcium and vitamin $\mathrm{D}$. When clinicians encounter such a clinical course, replacing calcium and vitamin $\mathrm{D}$, close monitoring and eliminating other possible causes of primary or secondary hyperparathyroidism are essential.

\section{References}

1. Mazokopakis EE (2018) Denosumab-induced Normocalcemic Hyperparathyroidism in a Woman with Postmenopausal Osteoporosis and Normal Renal Function. Curr Drug Saf 13: 214-216. Link: https://bit.ly/2Yuu26Q

2. Autio KA, Farooki A, Glezerman IG, Chan A, Schneider CW, et al. (2015) severe hypocalcemia associated with denosumab in metastatic castration-resistant prostate cancer: risk factors and precautions for treating physicians. Clin Genitourin Cancer 13: e305-e309. Link: https://bit.ly/3BnbvYJ

3. Muqeet Adnan M, Bhutta U, Iqbal T, AbdulMujeeb S, Haragsim L, et al. (2014) severe hypocalcemia due to denosumab in metastatic prostate cancer. Case Rep Nephrol 2014: 565393. Link: https://bit.ly/3ahbwl9

Discover a bigger Impact and Visibility of your article publication with

Peertechz Publications

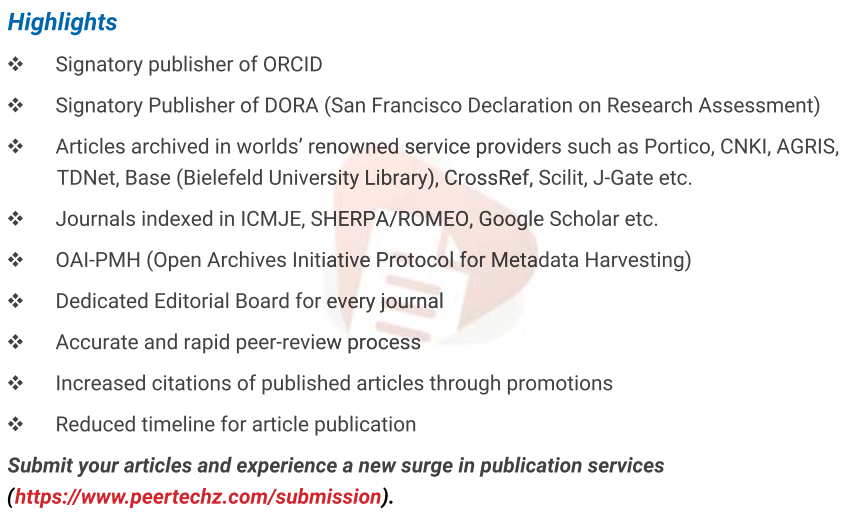

Peertechz journals wishes everlasting success in your every endeavours. 